\title{
Contribution of Agroforestry to Total Farmers' Revenue in Long Beluah Village, North Kalimantan Province - Indonesia
}

\author{
Marlan Usmani Putra ${ }^{1,2,}$, Rujehan ${ }^{2}$, Mustofa Agung Sardjono², Paulus Matius², \\ Ahyauddin $^{3}$ \\ ${ }^{1}$ Agrotechnology Program, Agriculture Faculty, University of Kaltara, Sengkawit Street, Bulungan Regency, North \\ Borneo Province, 77212. Indonesia \\ ${ }^{2}$ Forestry Science Doctoral Program, Forestry Faculty, University of Mulawarman Samarinda, Gunung Kelua Street, \\ Unmul Campus,Samarinda, Indonesia \\ ${ }^{3}$ Forestry Faculty, University of Jambi, Pinang Masak Unja Mendalo Campus, Jln Raya Jambi - Ma. Bulian KM 15, \\ Jambi, Indonesia \\ *Corresponding author. Email: usmani.marlan@gmail.com
}

\begin{abstract}
Agroforestry in Long Beluah Village can be developed to support welfare and maintain community economic stability. Agroforestry is one of the land management systems that can be offered to solve problems arising from food problems and at the same time provide socio-economic benefits to farmers. This research was conducted to determine agroforestry management and its contribution to the farmer's household economy. The analysis was carried out for four months starting from January-April 2019. As a guide in researching the field, this study used the stages of activities consisting of 1) surveying the research location, 2) selecting respondents, 3) Interviewing and filling out questionnaires, 4) Data collection secondary and supporting information, 5) Processing and data analysis. The results of this study: a) there are types of agroforestry plants belonging to farmers in Long Beluah village consisting of timber plants, plantation crops, fruit trees, perennial understorey, and seasonal understorey. b) The average amount of respondent's revenue from agroforestry farming for Long Beluah Village is Rp. 16,928,329 year ${ }^{-1}$, the type of fruit tree that contributed the highest to the respondent's average income was water guava, which amounted to Rp. $2,439,529$ year $^{-1}$ or $24.03 \%$ of the total fruit crop revenue. c) The average number of respondents' revenue from nonagroforestry is Rp. 21,812,132 year $^{-1}$. Meanwhile, the contribution of agroforestry is $43.70 \%$ of the total average farmer revenue.
\end{abstract}

Keywords: Agroforestry, Long Beluah Village, Revenue, Agroforestry Contribution

\section{INTRODUCTION}

Most of the Agroforestry Systems in Long Beluah Village follow the traditional agroforestry systems pattern and are carried out across generations. The reason why farmers apply an agroforestry system by combining seasonal plants (short cycle) and tree crops (long process) has become a local culture passed down from generation to generation from their previous ancestors [1]. Traditional agroforestry practices are described in detail in the Lembo system in the Dayak community in Central Mahakam, East Kalimantan [2].
The design originates from plants that grow spontaneously from seeds discarded on agricultural land or maintain and maintain existing regeneration trees, developed by cultivating plants and takes place continuously.

Based on brief observations, most of the community farming systems in the villages of Bulungan District in North Kalimantan Province apply an agroforestry system, so-called "Pula Pekelet" or "Lumaq" by Long Beluah village people who are dominated by traditional tribes "Dayak Kayan" [3]. This traditional agroforestry 


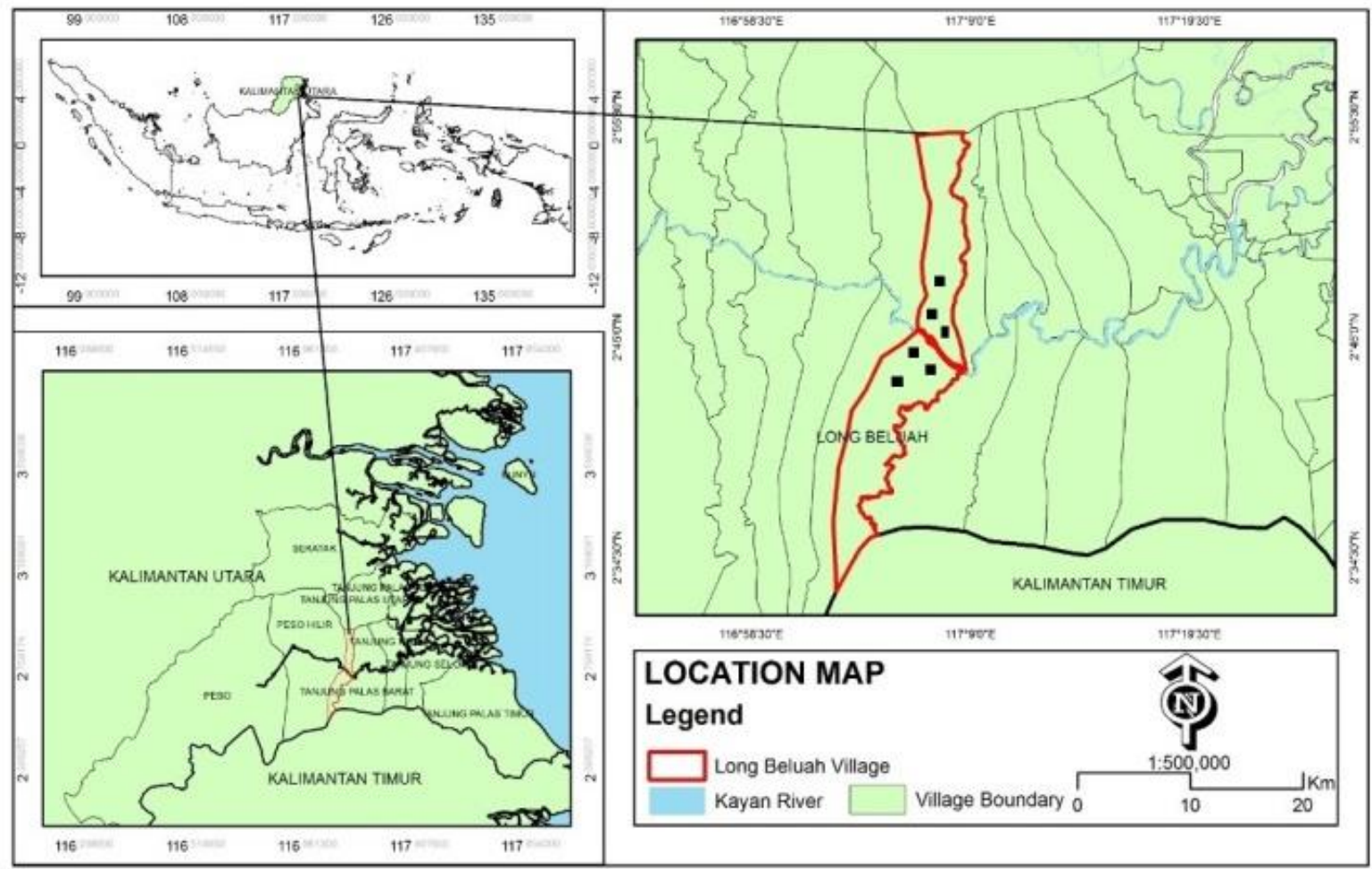

Figure 1 Location studies of Long Beluah village (•) Tanjung Palas Barat Subdistrict, Bulungan District, North Kalimantan Province, Indonesia.

system has been developed from their local culture. It can improve the community's standard of living, so this needs to prove whether agroforestry indeed contributes to the source of farmers' revenue.

Revenue itself is an indicator of the farmer's economy because its income will determine his life needs. The source of household income for farmers could be obtained from on-farm income, off-farm, and non-farm income. An agroforestry system's benefits can provide farmers with socio-economic services and increase productivity due to different yields to increase farmers' income [4]. Therefore, it is essential to do this research to know the income of agroforestry farmers and how much agroforestry contribution from farmer respondents in Long Beluah Village.

\section{MATERIALS AND METHODS}

\subsection{Place and Time}

This research was conducted in Long Beluah Village, Tanjung Palas Barat Subdistrict, Bulungan District, North Kalimantan Province, Indonesia. Graphically the village of Long Beluah is located at $2.731033\left(2^{\circ} 43^{\prime} 51.72^{\prime \prime} \mathrm{N}\right)$ and longitude 117.11471 (117 6'52.96”'E). The research was carried out for four months starting from January-April 2019, starting from field orientation to data processing.

\subsection{Sample Determination Method}

Determination of the sample or respondent is done by the purposive sampling method. The number of respondents was determined based on the Slovin Technique [5,6]. The Slovin formula used is:

$\mathbf{n}=\frac{\mathbf{N}}{\mathbf{N}(\mathbf{e}) \mathbf{2}+\mathbf{1}}$

Where:

$\mathrm{n}$ = number of respondents sampled in the study

$\mathrm{N}=$ number of farmers in the group members in the study area

e $=$ error limit $(15 \%)$

1 = constant number

Respondents were selected using purposive sampling based on community participation who implemented the agroforestry system. The number of respondents obtained was 34 farmers who owned the gardens.

\subsection{Research Activity Stages}

As a guide in researching the field, this study uses the stages of activities consisting of:

a. Initial survey of research locations 
The research location's initial survey was conducted to determine the research location's general conditions and explore prospective respondents' selection purposively according to the method. In this initial survey, researchers also held an audience with local customary leaders and village heads related to the research location.

b. Explanation of the research plan to respondents

All selected respondents were collected and then explained the research plan and a specific explanation of the procedures for filling out the research questionnaire.

c. Interviewing and filling out questionnaires

The researcher was assisted by several data collection team members who conducted direct interviews with the respondents and guided them in filling out the questionnaire.

d. Retrieval of secondary data and supporting information

Secondary data and supporting information were obtained from the village head, the Forestry Service of North Kalimantan Province, and literature studies through books and research journals.

e. Processing and analysis of data

Primary data obtained from direct interviews and questionnaires were recapitulated and analyzed quantitatively.

We looked for the expenditure, income, and contribution of agroforestry, which are calculated by:

1. Investigating and Quantifying Agroforestry Income [7].

$$
I_{\text {af }}=\Sigma R_{\text {af }}-\Sigma C_{\text {af }}
$$

Where:

$$
\begin{aligned}
\mathrm{I}_{\mathrm{af}}= & \begin{array}{l}
\text { income from agroforestry activities (IDR } \\
\text { year } \left.{ }^{-1}\right)
\end{array} \\
\mathrm{R}_{\mathrm{af}}= & \begin{array}{l}
\text { revenue from agroforestry activity products } \\
\left(\text { IDR year }{ }^{-1}\right)
\end{array} \\
\mathrm{C}_{\mathrm{af}}= & \begin{array}{l}
\text { expenditure for management of agroforestry } \\
\text { activities (IDR year }
\end{array}
\end{aligned}
$$

2. Investigating and Calculating income from nonagroforestry activities [7].

$$
I_{\text {naf }}=\Sigma R_{\text {naf }}-\Sigma C_{\text {naf }}
$$

Where:

$$
\begin{aligned}
\mathrm{I}_{\text {naf }}= & \begin{array}{l}
\text { total income from non-agroforestry activities } \\
\\
\left(\text { IDR year }{ }^{-1}\right)
\end{array} \\
\mathrm{R}_{\text {naf }}= & \begin{array}{l}
\text { revenue each from non-agroforestry } \\
\text { activities (IDR year } \left.{ }^{-1}\right)
\end{array}
\end{aligned}
$$

$$
\begin{aligned}
\mathrm{C}_{\text {naf }}= & \begin{array}{l}
\text { expenditure on non-agroforestry activities } \\
(\text { IDR year }
\end{array} \text { ) }
\end{aligned}
$$

3. Calculating the Contribution of Agroforestry (CA) [8].

$$
\mathrm{CA}=\frac{\text { Revenue from Agroforestry }}{\text { Total revenue }} \times 100 \%
$$

\section{RESULT AND DISCUSSION}

\subsection{General Conditions of Research Location}

In general, Long Beluah Village has a flat to wavy topography. Hilly area, with an altitude reaching 15-120 $\mathrm{m}$ above sea level. At the same time, the flat areas are along the river. According to soil mapping, the most dominant soil type is podzolic. The characteristics of the soil solum are relatively thick $(90-180 \mathrm{~cm})$, the color of the soil is reddish-brown to yellowish-brown with a real horizon, textured from sandy loam to clay, $\mathrm{pH}$ ranges from 4.0 to 5.5 , moderate to slow permeability, and easy erosion sensitivity [9].

\subsection{Agroforestry System}

The village's agroforestry is a complex system with irregular spacing. It comprises various types of woody plants, plantation crops, fruit trees, perennials, and understory crops. Agroforestry is an integrated land system that combines trees with various crops, carried out either together or in rotation to produce optimal and sustainable land use [10]. The types of agroforestry plants belonging to farmers in Long Beluah village consist of:

a. Timber plants such as acacia (Acacia mangium), Lamtoro (Leucaena leucocophala), areca nut (Areca catechu), meranti (Shorea sp.), Bengkirai (Shorea laevis), gamal (Gliricidia sepium).

b. Plantation crops such as coffee (Coffea spp.), Coconut (Coconus nucifera), sugar palm (Arenga pinnata), and cocoa (Theobroma cacao L).

c. Fruit crops such as durian (Durio zibethinus), lai (Durio kutejensis), kuweni (Mangifera odorata), petai (Parkia speciosa), jackfruit (Artocarpus heterophyllus), breadfruit (Artocarpus altilis), avocado (Persea americana), jengkol (Archidendron pauciflorum), water guava (Syzygium aqueum), duku, langsat (Lansium domesticum), rambutan (Nephelium lappaceum), orange (Citrus spp.), Longan (Dimocarpus longan).

d. Perennial crops such as cayenne pepper (Capsicum frustescent), banana (Musa spp.), Pineapple (Ananas comosus), papaya (Carica papaya), pepper (Piper ningrum), and grass.

e. Seasonal root crops such as betel (Piper beetle), red betel (Piper ornatum), bangle (Zingiber montanum), 
ginger (Zingiber officinale Rosc), galangal (Kaempferia galanga), turmeric (Curcuma domisticae), red ginger (Zingiber officinale var. rubrum), ginger (Curcuma zanthorrhiza), eggplant (Solanum lycopersicum), sweet potato (Ipomoea batatas), cassava (Manihot utilissima) and peanuts (Arachis hypogeae), green beans (Vigna radiata), corn (Zea mays), tomatoes (Solanum lycopersicum), cucumber (Cucumis sativus), bitter melon (Momordica charantia), pumpkin (Cucurbita), melon (Cucumis melo), watermelon (Citrullus lanatus), long beans (Zingiber officinale), green beans (Phaseolus vulgaris), rice (Oryza sativa).

\subsection{Income Agroforestry Farming}

Agroforestry farmer respondents' income is calculated in the last year based on the source of revenue and the farming business's cost. Payment from agroforestry is calculated from timber, food crops, estate crops, medicinal plants, and livestock on land owned by farmers. Data on income, expenses, and respondent revenue are presented in Table 1.

Table 1. Average revenues, costs and income of respondents from Long Beluah village agroforestry farming

\begin{tabular}{|c|c|c|}
\hline No. & Source & $\begin{array}{l}\text { Average } \\
(\text { IDR year-1) }\end{array}$ \\
\hline 1. & \multicolumn{2}{|l|}{ Agroforestry Farmers' Revenue } \\
\hline & a. Wood & $1,411,765$ \\
\hline & b. Fruit Plants & $10,152,706$ \\
\hline & c. Crops & $4,522,706$ \\
\hline & d. Plantation crops & $2,854,824$ \\
\hline & e. Medicinal plants & $1,381,976$ \\
\hline & f. Livestock & $2,223,529$ \\
\hline & Total Revenue & $22,547,506$ \\
\hline \multirow[t]{5}{*}{2.} & \multicolumn{2}{|l|}{ Agroforestry Farming Costs } \\
\hline & a. Labor costs & $1,658,118$ \\
\hline & $\begin{array}{l}\text { b. Agricultural Equipment and } \\
\text { Materials Costs }\end{array}$ & $2,210,824$ \\
\hline & c. Etc & $1,750,235$ \\
\hline & Total cost & $5,619,176$ \\
\hline 3. & $\begin{array}{l}\text { Income } \\
\text { (Revenue - Costs) }\end{array}$ & $16,928,329$ \\
\hline & average per month & $1,410,694$ \\
\hline
\end{tabular}

Table 1 shows that overall agricultural revenue derived from agroforestry is greater than agroforestry farming costs. In other words, it can be said that agroforestry financing is lower. The interviews explained that agroforestry farming, cultivation techniques are not as intensive as monoculture farming, especially in terms of plant care, so that the financing of agroforestry farming does not require high costs. The average amount of farm costs for each respondent in Long Beluah village is IDR 5,619,176 year ${ }^{-1}$.

Table 1 also shows that the use of agroforestry land owned by respondents provides benefits that can meet the community's economic needs. This can be seen from the respondents' income in Long Beluah Village, IDR $16,928,329$ year-1 or IDR $1,410,694$. Following $[11,12]$, agroforestry is the right choice in using land owned by the community / farmers because it can provide revenue in the short term for daily living costs obtained from seasonal crops and long-term income as savings from forestry commodities.

Table 2. Average Amount of Respondents Received from Fruit Crops in Agroforestry Systems

\begin{tabular}{|c|c|c|c|}
\hline No. & Commodity & $\begin{array}{c}\text { Revenue } \\
\left(\text { IDR year }{ }^{-1} \text { ) }\right.\end{array}$ & $\begin{array}{c}\text { Percentage } \\
\text { (\%) }\end{array}$ \\
\hline 1 & Durian & $1,900,588$ & 18.72 \\
\hline 2 & Elai & 727,941 & 7.17 \\
\hline 3 & Mango & 170,294 & 1.68 \\
\hline 4 & Petai & 626,471 & 6.17 \\
\hline 5 & Jackfruit & 101,647 & 1.00 \\
\hline 6 & Breadfruit & 561,176 & 5.53 \\
\hline 7 & Lamtoro & 31,765 & 0.31 \\
\hline 8 & Avocado & 19,059 & 0.19 \\
\hline 9 & Jengkol & 121,765 & 1.20 \\
\hline 10 & $\begin{array}{l}\text { Guava water } \\
\text { "Honey" }\end{array}$ & $2,439,529$ & 24.03 \\
\hline 11 & Duku & $1,921,765$ & 18.93 \\
\hline 12 & Langsat & 486,000 & 4.79 \\
\hline 13 & Rambutan & 716,471 & 7.06 \\
\hline 14 & Orange & 304,412 & 3.00 \\
\hline 15 & Longan & 23,824 & 0.23 \\
\hline & Total & $10,152,706$ & 100 \\
\hline \multicolumn{2}{|c|}{ Average per month } & 846,059 & \\
\hline
\end{tabular}

The respondent's annual revenue for agroforestry products from Long Beluah village as the most significant contributor was the revenue from fruit trees, amounting to IDR 10,152,706 as described in Table 2. Types of fruit trees that contributed the highest to income was water guava "honey", amounting to IDR $2,439,529$ year-1 $^{-1}(24.03 \%)$ because water guava "honey" is a leading fruit commodity in Bulungan Regency, North Kalimantan Province [13] 


\subsection{Non-Agroforestry Income}

The level of dependence of agroforestry farmer communities in Long Beluah village on the forest area is relatively high, as reflected by various land use activities. The interviews indicated that most respondents said they did not only rely on their revenue from agroforestry but also from non-agroforestry activities, including having a side job.

Table 3. Average revenue, costs and $s$ income of respondents from non-agroforestry farming in Long Beluah village

\begin{tabular}{|c|c|c|}
\hline No. & Source & $\begin{array}{c}\text { Average } \\
(\text { IDR year-1) }\end{array}$ \\
\hline 1. & \multicolumn{2}{|c|}{ Non-Agroforestry Farming revenue } \\
\hline & a. Monoculture Agriculture & $11,232,721$ \\
\hline & b. Fishery & 323,529 \\
\hline & c. Other revenu & $5,391,176$ \\
\hline & d. Side job : & - \\
\hline & - PNS / ASN & $1,235,294$ \\
\hline & - Fisherman & $5,647,059$ \\
\hline & - Trader & $21,670,588$ \\
\hline & - Builder & $9,058,824$ \\
\hline & Total revenue & $54,559,191$ \\
\hline \multirow[t]{9}{*}{2.} & \multicolumn{2}{|l|}{ Non-Agroforestry Costs } \\
\hline & a. Food & $7,473,529$ \\
\hline & b. Clothing & $3,688,235$ \\
\hline & c. Educationn & $9,035,294$ \\
\hline & d. Health & $1,667,647$ \\
\hline & e. Household Facilities & $4,235,294$ \\
\hline & f. Incidental Costs & $1,000,000$ \\
\hline & $\begin{array}{l}\text { g.Non-Agroforestry } \\
\text { Farming }\end{array}$ & $5,647,059$ \\
\hline & Total cost & $32,747,059$ \\
\hline 3. & Income ( Revenue - Costs) & $21,812,132$ \\
\hline & average per month & $1,817,678$ \\
\hline
\end{tabular}

Respondents' revenue originating from nonagroforestry is calculated from monoculture farming, livestock, fisheries, salaries or wages, and other income. Meanwhile, respondents' non-agroforestry cost components are from the cost of food, clothing, education, health, household facilities, incidental expenses, and non-agroforestry or monoculture farming costs. Income after deducting the cost, the respondent's acceptance is obtained. The highest respondent's nonagroforestry income for Long Beluah Village was IDR
21.812.132 year $^{-1}$. Data on revenues, expenses, and nonagroforestry revenues are presented in Table 3.

Table 3 provides information that the largest revenue contributor to Long Beluah Village is from a side job of trading, namely IDR 21.670.588 year $^{-1}$. This is because the respondent, apart from farming, also has a side job as a trader. The interviews with respondents who have side jobs as traders found out that the maintenance and harvesting of agroforestry plants are carried out at any time. If activities require a lot of labor, such as planting and harvesting mountain rice, they will pay workers to help. Respondents considered trading as having the advantage of having "cash". The circulation of money was faster, and the income from trading was higher because the percentage of farmer respondents who had a side job by trading was quite dominant, namely $38.23 \%$.

\subsection{Contribution of Agroforestry Systems}

The difference between the average total revenue and the average total cost is a profit of IDR 38,740,462 year $^{-1}$ for agroforestry farmers in Long Beluah Village. Comparison between income and expense for all respondents in Long Beluah Village can be seen in Table 4.

Table 4. Comparison of average household revenue and cost of respondents

\begin{tabular}{|c|c|c|}
\hline No. & Indicator & $\begin{array}{c}\text { Average } \\
(\text { IDR year-1) }\end{array}$ \\
\hline \multirow[t]{3}{*}{1} & Average total Revenue & $77,106,697$ \\
\hline & Agroforestry Revenue & $22,547,506$ \\
\hline & Non-Agroforestry Revenue & $54,559,191$ \\
\hline \multirow[t]{3}{*}{2} & Total Average Cost & $38,366,235$ \\
\hline & Agroforestry Costs & $5,619,176$ \\
\hline & Non-Agroforestry Costs & $32,747,059$ \\
\hline 3 & Profit (Revenue - Cost) & $38,740,462$ \\
\hline
\end{tabular}

Table 4 shows that if a comparison is made between the respondent's revenue and cost, it is found that the respondent's income is higher than his expenses. This means that farmers can finance their needs both from agroforestry and non-agroforestry products. An agroforestry system in Long Beluah village can be a better and more profitable alternative to land use. An excellent policy for facilitating agroforestry's contribution is essential. It would make agroforestry continues to provide a positive trend. The percentage contribution of agroforestry and non-agroforestry to the respondent's revenue is presented in Table 5.

Table 5 shows that agroforestry's contribution to farmers' total revenue in Long Beluah Village is relatively high $(43.70 \%)$. The agroforestry community forest is a side revenue and is incidental with a range of 
not more than $10 \%$ of total income [14]. But in reality, in the study village, its contribution was far above $10 \%$. This means that agroforestry land in Long Beluah village has a significant role and positively impacts the farmer's economy.

Table 5. Contribution of agroforestry and non-agroforestry to respondent.

\begin{tabular}{|c|l|c|c|}
\hline No. & $\begin{array}{c}\text { Source of } \\
\text { Revenue }\end{array}$ & $\begin{array}{c}\text { Total Average } \\
\text { Farmers' } \\
\text { Revenue } \\
\text { (IDR year-1) }\end{array}$ & $\begin{array}{c}\text { Contribution } \\
\text { to Farmers' } \\
\text { Revenue } \\
(\%)\end{array}$ \\
\hline 1 & Agroforestry & $16,928,329$ & 43.70 \\
\hline 2 & Non-agroforestry & $21,812,132$ & 56.30 \\
\hline & Amount & $38,740,462$ & 100.00 \\
\hline
\end{tabular}

\section{CONCLUSION}

The types of agroforestry crops in Long Beluah are timber, plantation crops, fruit trees, perennial understorey, and seasonal understorey. The average amount of respondent's revenue from agroforestry farming for Long Beluah Village was IDR 16,928,329 year $^{-1}$, the type of fruit tree that contributed the highest to the average income of the respondents was water guava "honey", namely IDR 2,439,529 year ${ }^{-1}$ or $24.03 \%$ of the total fruit crop revenue.

The average number of respondents' income from non-agroforestry was IDR 21,812,132 year $^{-1}$. Meanwhile, the contribution of agroforestry is $43.70 \%$ of the total average farmer income.

\section{ACKNOWLEDGMENTS}

We want to thank the Dean of the Faculty of Forestry, Mulawarman University, and the Head of the Mulawarman University Forestry Science Doctoral Study Program for their assistance. Thank you also to the Chancellor and Dean of the Faculty of Agriculture, University of Kaltara for their support and to all the people of Long Beluah Village who have facilitated this research. Thank you very much.

\section{REFERENCES}

[1] A. Uluk, M. Sudana, E. Wollenberg, Ketergantungan Masyarakat Dayak terhadap Hutan di Sekitar Taman Nasional Kayan Mentarang, Center For International Forestry Research (CIFOR), Bogor, 2001.

[2] M.A. Sardjono, Budidaya Lembo di Kalimantan Timur: Satu Model untuk Pengembangan Pemanfaatan Lahan Agroforestri di Daerah Tropis Lembab, Fahutan Unmul, 1995.
[3] M.U. Putra, Praktek Agroforestri Berbasis Kearifan Lokal di Kabupaten Bulungan Provinsi Kalimantan Utara, Disertasi Program Doktor Ilmu Kehutanan Universitas Mulawarman, 2020.

[4] D.K. Sari, D. Haryono, N. Rosanti, Analisis Pendapatan dan Tingkat Kesejahteraan Rumah Tangga Petani Jagung di Kecamatan Natar Kabupaten Lampung Selatan, Jurnal Ilmu-ilmu Agribisnis (Journal of Agribusiness Science), 2(1), 2014.

[5] T. Amirin, Populasi dan Sampel Penelitian: Ukuran Sampel Rumus Slovin 4, Erlangga, 2011.

[6] J. Soewadji, Pengantar Metodologi Penelitian, Mitra Wacana Media, 2012, pp. 134-135.

[7] E. Koswara, Peranan Kontribusi Hutan Rakyat Terhadap Pendapatan Rumah Tangga Petani (Studi Kasus Pekon Pahmungan Kecamatan Pesisir Tengah Kabupaten Lampung Barat), Skripsi, Institut Pertanian Bogor, 2006.

[8] S.B. Zega., A. Purwoko, T. Martial, Analisis Pengelolaan Agroforestry dan Kontribusinya Terhadap Perekonomian Masyarakat, Peronema Forestry Science Journal, 2(2), 2013.

[9] Central Bureau of Statistics, Kecamatan Tanjung Palas Barat Dalam Angka, Badan Pusat Statistik Kabupaten Bulungan (BPS), 2019.

[10] K. Hairiah, M.A. Sardjono, S. Sabarnurdin, Pengantar Agroforestri, World Agroforestry Centre (ICRAF), 2003.

[11] P. Kusumedi, N.A. Jariyah, Analisis Finansial Pengelolaan Agroforestri dengan Pola Sengon Kapulaga di Desa Tirip, Kecamatan Wadaslintang Kabupaten Wonosobo. Jurnal Penelitian Sosial Ekonomi Kehutanan, 7(2), 2010. pp. 100-93.

[12] B.T. Premono, S. Lestari, Analisis Finansial Agroforestri Kayu Bawang (Dysoxilum mollissium Blume) dan Kebutuhan Lahan Minimum di Provinsi Bengkulu, Jurnal Penelitian Sosial Ekonomi Kehutanan, 10(4), 2013, pp. 211-223.

[13] A. Asri, Jambu Madu Bulungan Prospeknya Semanis Madu, 2009, Available from: http://www.vivaborneo.com/?p=786.

[14] D. Suharjito, Hutan Rakyat di Jawa: Perannya dalam Perekonomian Desa, Program Penelitian dan Pengembangan Kehutanan Masyarakat (P3KM), 2000 . 